\title{
The Relation between the Tetanus Toxin-Fixing and Influenza Virus-Inhibiting Properties of Ganglioside
}

\author{
BY A. W. BERNHEIMER* AND W. E. VAN HEYNINGEN \\ Sir William Dunn School of Pathology, University of Oxford
}

(Received 25 July 1960)

\begin{abstract}
SUMMARY
The capacity of a number of gangliosides to fix tetanus toxin and to inhibit haemagglutination by influenza virus was investigated. Toxin fixation increased with total sialic acid content but not in strict proportion. Whether or not the sialic acid is bound by neuraminidase-labile linkage appears to be irrelevant in determining whether toxin is fixed. Viral inhibition by ganglioside also is related to the total content of sialic acid; but there exists at least one ganglioside which has very little capacity to react with virus and whose sialic acid is virtually all insensitive to neuraminidase. Tetanus toxin does not prevent neuraminidase from attacking ganglioside.
\end{abstract}

\section{INTRODUCTION}

Ganglioside from nervous tissue has been shown to act as a specific receptor for tetanus toxin (Van Heyningen, 1959) and the sialic acid residue(s) of this compound has been shown to be essential for toxin-fixation (Van Heyningen \& Miller, 1961). It is well known that sialic acid-containing substances also act as influenza virus receptors. Rosenberg, Howe \& Chargaff (1956) found that their preparation of mucolipid, which contained a polypeptide moiety in addition to ganglioside, inhibited influenza virus, and was susceptible to viral and cholera neuraminidase, whereas samples of ganglioside which did not contain amino acid residues were inactive. They considered that the polypeptide moiety, in addition to the sialic acid residue, was essential for viral inhibitory activity. It has been observed that amino acids are present in ganglioside preparations extracted from wet brain, but not in preparations extracted from acetone-dehydrated brain (Folch, Arsove \& Meath, 1951; Svennerholm, 1956). Bogoch (1957) showed that a preparation of brain ganglioside from wet brain inhibited viral haemagglutination. Kuhn (1958) separated two fractions of brain ganglioside from dehydrated brain on a cellulose column eluted with methanol + pyridine + water and found that the more rapidly moving fraction (G2), containing $21 \%$ sialic acid, did not inhibit viral haemagglutination and was not susceptible to Vibrio cholerae neuraminidase; the more slowly moving fraction (G0.5) containing $31 \%$ sialic acid, inhibited viral haemagglutination and was susceptible to neuraminidase. Van Heyningen \& Miller (1961) separated brain ganglioside (prepared from dehydrated brain and containing no amino acid

* Present address: Department of Microbiology, New York University College of Medicine, New York. 


\section{A. W. Bernheimer and W. E. van HeYningen}

residues) into 'fast' and 'slow' fractions from silicic acid columns eluted with methanol + chloroform. The 'fast' preparation contained $0.75 \mu$ mole sialic acid $/ \mathrm{mg}$. and the 'slow' $0.93 \mu \mathrm{mole} / \mathrm{mg}$. The tetanus toxin-fixing capacities of these fractions were approximately proportional to their sialic acid contents. They also showed that the mucolipid preparation of Rosenberg et al. (1956) was 'slow' and contained $0.89 \mu$ mole sialic acid/mg., whereas an amino acid-free preparation supplied by Professor E. Klenk was 'fast' and contained 0.66 $\mu$ mole sialic acid/mg. The tetanus toxin-fixing capacities of these preparations were also roughly proportional to their sialic acid contents. We have now investigated the influenza virus-inhibiting properties of these various ganglioside preparations in relation to their toxin-fixing capacities.

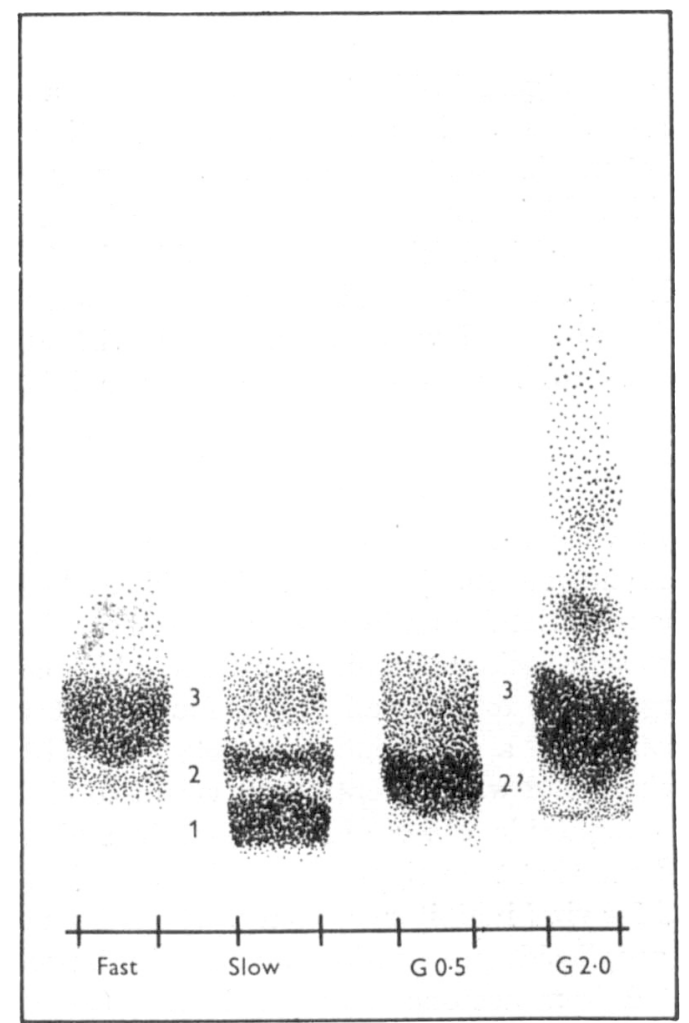

Fig. 1. Paper chromatograms of various ganglioside preparations. Components 1 and 2 metachromatic, 3 non-metachromatic.

\section{METHODS}

Ganglioside preparations. The preparation (or source) and properties of the 'partially purified', 'fast', 'slow', 'Chargaff' and 'Klenk' gangliosides are described in the preceding paper (Van Heyningen \& Miller, 1961). The G 2.0 and G0.5 preparations were kindly supplied by Professor Richard Kuhn. Their paper chromatographic behaviour in comparison with 'fast' and 'slow' ganglioside preparations is shown in Fig. 1. 
Paper chromatography. As deseribed by Van Heyningen \& Miller (1961), except that for Fig. 3 the ratio of di-isobutylketone, acetic acid, water was $40: 25: 5$, rather than $40: 30: 7$.

Assays. Total sialic acid was estimated by the resorcinol method of Svennerholm (1957); free sialic acid by the thiobarbituric acid assay of Warren (1959); tetanustoxin fixing capacity (RU/mg.) by the method of Van Heyningen \& Miller (1961); influenza virus-inhibiting capacity essentially by the method of Howe (1951). The PR 8 strain of influenza virus was harvested from eggs, the combined allantoic fluid centrifuged and the sedimented virus resuspended in 0.1 vol. $0.15 \mathrm{M}-\mathrm{NaCl}$. Virus prepared in this way (haemagglutinin titre 64,000) was kindly supplied by Dr A. Isaacs. Indicator virus was prepared by heating this preparation for $30 \mathrm{~min}$. at $55-56^{\circ}$. The titrations were carried out in MRC pattern Perspex plates. Serial twofold dilutions of ganglioside contained in $0.2 \mathrm{ml} .0 \cdot 15 \mathrm{M}-\mathrm{NaCl}$, buffered to $\mathrm{pH} 7 \cdot 2$ with $0.01 \mathrm{M}$-phosphate, were mixed with 1-2 haemagglutinin units of indicator virus and allowed to stand in the refrigerator for $30 \mathrm{~min} . ; 0.1 \mathrm{ml}$. of a $2 \%$ suspension of washed chicken erythrocytes was then added, and after standing 1-2 hr. in the cold, the patterns of the sedimented erythrocytes were observed. The end-point used was the smallest amount of ganglioside giving just short of complete inhibition of haemagglutination.

Neuraminidase. Two preparations were used: (a) crude freeze-dried Vibrio cholerae filtrate (N. V. Philips-Roxane, Amsterdam), (b) crystalline $V$. cholerae neuraminidase kindly supplied by Dr G. L. Ada. Neuraminidase (RDE) activity was estimated by the method of Burnet \& Stone (1947). The Ca + acetate + saline used in experiments with neuraminidase contained per 1 . distilled water: 12.38 g. sodium acetate, $5 \cdot 0 \mathrm{~g} \cdot \mathrm{NaCl}, 1 \cdot 0 \mathrm{~g} \cdot \mathrm{CaCl}_{2} \cdot \mathrm{H}_{2} \mathrm{O}$; adjusted to $\mathrm{pH} 6 \cdot 2$ with $2 \mathrm{~N}$-acetic acid.

\section{RESULTS}

\section{Inhibition of haemagglutination}

The viral haemagglutination-inhibiting property of the various ganglioside preparations is shown in Table 1.

\section{Action of neuraminidase on ganglioside}

The thiobarbituric acid assay (Warren, 1959) is useful for the measurement of enzymic liberation of sialic acid from ganglioside since it estimates only free sialic acid. Figure $2 a$ shows the time course of the liberation of sialic acid from 'slow' ganglioside by crude Vibrio cholerae neuraminidase ( 75 units/ml.). Maximal splitting was reached in about $8 \mathrm{hr}$. Figure $2 b$ shows the liberation of sialic acid from 'slow' ganglioside by increasing concentrations of crystalline neuraminidase in $16 \mathrm{hr}$. Maximal splitting was obtained with 75-100 enzyme units/ml.

Comparative susceptibility of various ganglioside preparations to neuraminidase. Neuraminidase-labile sialic acid of the several ganglioside preparations was estimated by incubating $160 \mu \mathrm{g}$. ganglioside with 4000 units of crystalline neuraminidase in a volume of $0.4 \mathrm{ml}$, $\mathrm{pH} \mathrm{6.2,} \mathrm{at} 36^{\circ}$. After $16 \mathrm{hr}$. free sialic acid was measured (Warren, 1959) and the values obtained corrected for small amounts of colour and turbidity given by untreated ganglioside. The results are shown in Table 1. 


\section{A. W. Bernheimer and W. E. van Heyningen}

Table 1. Chromatographic behaviour, neuraminidase-sensitivity, viral-inhibition and toxin-fixation of ganglioside preparations

\begin{tabular}{|c|c|c|c|c|c|c|c|}
\hline \multirow[b]{2}{*}{$\begin{array}{l}\text { Ganglioside } \\
\text { preparation }\end{array}$} & \multicolumn{2}{|c|}{$\begin{array}{l}\text { Chromatographic properties } \\
\text { of main component(s) }\end{array}$} & \multirow{2}{*}{$\begin{array}{c}\text { Total } \\
\text { sialic acid } \\
(\mu \mathrm{mole} / \mathrm{mg} .)\end{array}$} & \multirow{2}{*}{\multicolumn{2}{|c|}{ 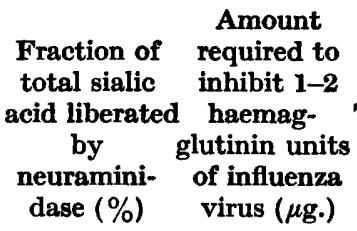 }} & \multicolumn{2}{|c|}{ Toxin-fixing capacity } \\
\hline & Movement & $\begin{array}{l}\text { Staining with } \\
\text { cresyl violet }\end{array}$ & & & & $\mathbf{R U} / \mathbf{m g}$. & $\begin{array}{l}\mathrm{RU} / \mu \mathrm{mole} \\
\text { sialic acid }\end{array}$ \\
\hline $\begin{array}{l}\text { Partially } \\
\text { purified }\end{array}$ & $\begin{array}{l}\text { Fast and } \\
\text { slow }\end{array}$ & $\mathbf{N}$ and $\mathrm{M}^{*}$ & $0 \cdot 73$ & 44 & 8 & 1100 & 1505 \\
\hline Fast & Fast & $\mathbf{N}$ & $0 \cdot 75$ & $\mathbf{3 5}$ & 8 & 950 & 1280 \\
\hline Slow & Slow & $\mathbf{M}$ & 0.98 & 57 & 1 & 1810 & 1400 \\
\hline Kuhn G0.5 & Slow & $\mathbf{M}$ & $0 \cdot 82$ & 33 & 0.5 & 820 & 1000 \\
\hline Kuhn G2.0 & Fast & $\mathbf{N}$ & 0.58 & $\mathbf{2}$ & 20 & 580 & 1000 \\
\hline $\begin{array}{l}\text { Chargaff } \\
\text { mucolipid }\end{array}$ & Slow & $\mathbf{M}$ & $0 \cdot 89$ & 47 & 0.5 & 1190 & 1340 \\
\hline Klenk & Fast & $\mathbf{N}$ & 0.66 & 21 & 10 & 540 & 820 \\
\hline
\end{tabular}

*M = metachromatic, i.e. stains pink-mauve; $\mathbf{N}=$ non-metachromatic, i.e. stains blue-mauve.

A preparation of influenza virus, 50 times as concentrated (the greatest practicable) as the allantoic fluid from which it was derived, released $48 \%$ of the total sialic acid of the 'slow' ganglioside in $16 \mathrm{hr}$. at $36^{\circ}$ (compare $57 \%$ released by Vibrio cholerae neuraminidase).

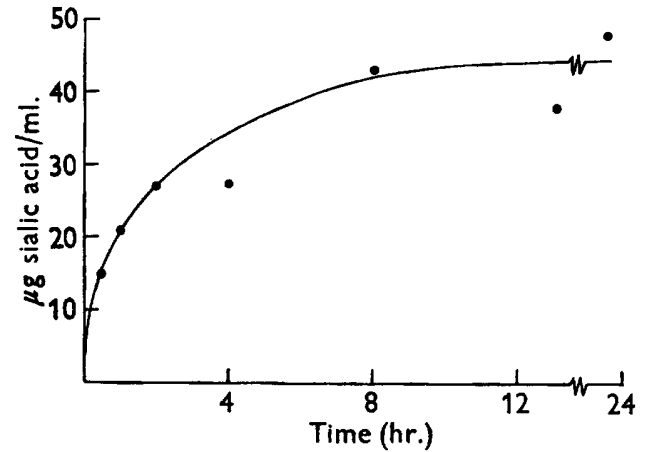

(a)

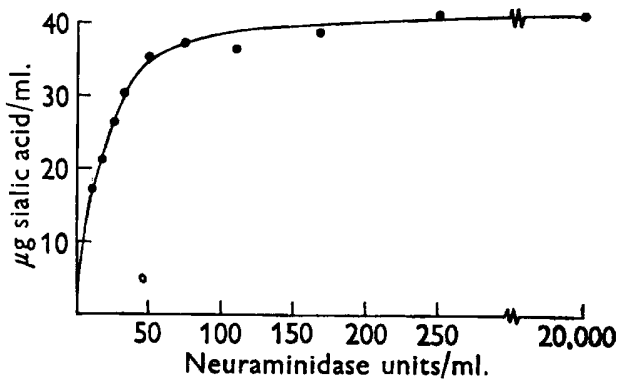

(b)

Fig. 2a. Course of appearance of sialic acid in a mixture of ganglioside and Vibrio cholerae filtrate. One $\mathrm{ml}$. crude $V$. cholerae filtrate reconstituted to twice its original volume with calcium + acetate + saline ( $\mathrm{pH} \mathrm{6.2)}$ ) was added to one ml. of the same diluent containing $0.8 \mathrm{ml}$. 'slow' ganglioside. During incubation at $36^{\circ}, 0 \cdot 2 \mathrm{ml}$. samples were removed at the times indicated and delivered into tubes containing $0.1 \mathrm{ml}$. sodium periodate in phosphoric acid, and free sialic acid subsequently estimated. The values are corrected for colour given by the $V$. cholerae filtrate.

Fig. 2b. Liberation of sialic acid as a function of enzyme concentration. Each point represents the free sialic acid found after incubating for $16 \mathrm{hr}$. at $36^{\circ} 80 \mu \mathrm{g}$. 'slow' ganglioside in $0.1 \mathrm{ml}$. calcium + acetate + saline (containing $0.1 \%$ gelatin) $+0.1 \mathrm{ml}$. crystalline $\boldsymbol{V}$. cholerae neuraminidase in same diluent. The values are corrected for the small amount of colour given by the ganglioside alone. 


\section{Fixation of tetanus toxin}

The tetanus toxin-fixing capacities of the various ganglioside preparations are shown in Table 1. It is evident that even when practically none of the sialic acid was neuraminidase-sensitive (as in preparation G 2.0) ganglioside still fixed toxin. The data suggest that neuraminidase-insensitive as well as neuraminidase-sensitive sialic acid is concerned in toxin-fixation. In order further to test this point a solution

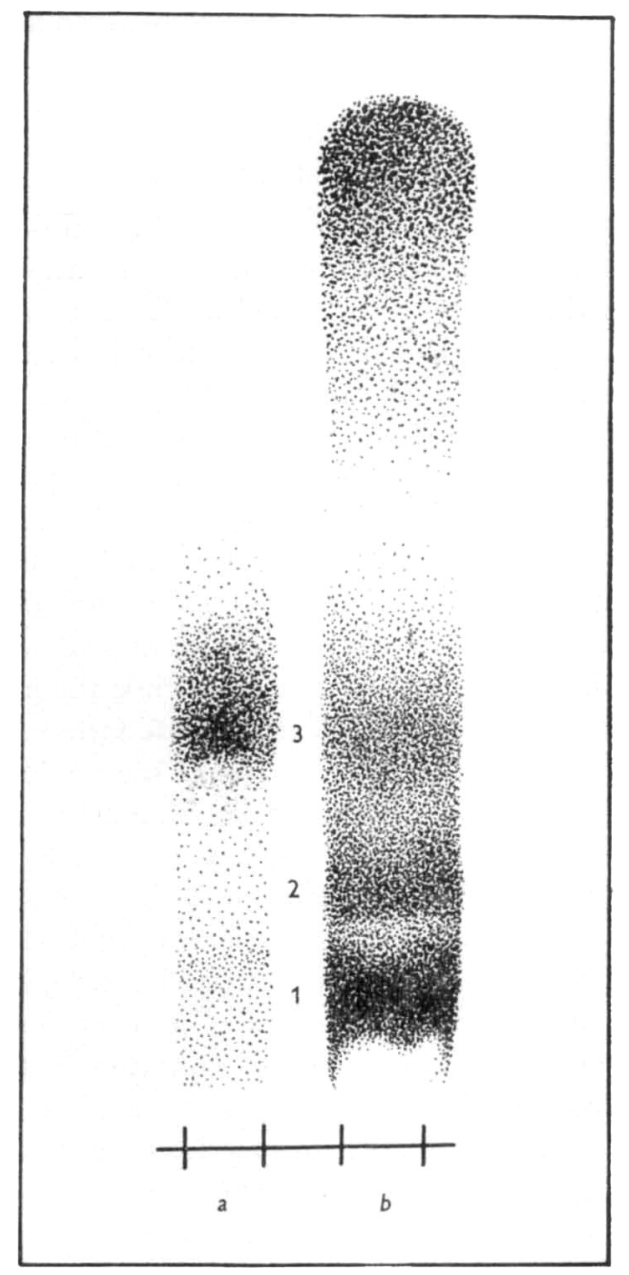

Fig. 3. Paper chromatogram of 'slow' ganglioside after treatment with neuraminidase (a) compared with partially purified ganglioside (b). Components 1 and 2 metachromatic, 3 non-metachromatic.

containing 1.2 mg. 'slow' ganglioside and 6000 units neuraminidase in $3 \mathrm{ml}$. Ca+ acetate + saline was incubated for $16 \mathrm{hr}$., with liberation of $48 \%$ of the total sialic acid. The mixture was dialysed overnight against running tap water and freezedried. The product was found to contain $580 \mathrm{RU} / \mathrm{mg}$., or $1140 \mathrm{RU} / \mu$ mole sialic acid.

Figure 3 shows a paper chromatogram of the neuraminidase-treated preparation, 
compared with unfractionated ganglioside. It can be seen that the neuraminidase had converted 'slow' ganglioside into 'fast' ganglioside.

The possibility was tested that tetanus toxin might competitively inhibit the action of neuraminidase on ganglioside, but as much as $2.6 \mathrm{mg}$. toxin/ml. did not significantly diminish the rate of liberation of sialic acid from ganglioside as compared to that of neuraminidase acting on ganglioside in the absence of toxin. The concentration of toxin was sufficient to combine with all the ganglioside present; the concentration of neuraminidase was $c .0 .01 \mu \mathrm{g} . / \mathrm{ml}$. We were unable to test the reverse concentrations of toxin and neuraminidase because of the limited supply of pure neuraminidase at our disposal.

\section{DISCUSSION}

Differences in the ability of various gangliosides to inhibit viral haemagglutination appear to reside in differences in sialic acid content rather than in the presence or absence of amino acid residues as suggested by Rosenberg et al. (1956). Not all of the sialic acid which is responsible for viral inhibition is necessarily neuraminidasesensitive, for comparison of the G0.5 and 'slow' preparations shows the proportion of neuraminidase-sensitive sialic acid to be much lower in G0.5 than in 'slow', while the latter, if anything, had slightly less viral inhibitory capacity.

The gangliosides having a greater sialic content are 'slow' and metachromatic on paper chromatography, and Figs. 1 and 3 (as well as Fig. 6 in Van Heyningen \& Miller, 1961) show that there are apparently two such gangliosides. There is a suggestion in Fig. 3 that the second of these gangliosides is the same as G0.5. Since the G 0.5 has $33 \%$ neuraminidase-sensitive sialic acid while the mixture of the first and second components (i.e. 'slow') has $57 \%$ neuraminidase-sensitive sialic acid, the proportion of neuraminidase-sensitive sialic acid in the first component is probably greater than $57 \%$. It is unlikely that the two metachromatic gangliosides are identical with the two gangliosides of Klenk \& Gielen (1960) since these latter are 'fast' and non-metachromatic (Van Heyningen \& Miller, 1961).

The work reported in this paper confirms the observation of Van Heyningen \& Miller (1961) that tetanus toxin-fixation by ganglioside is dependent upon sialic acid content. Although not all the sialic acid of ganglioside is concerned in viral inhibition, it does all appear to be concerned in toxin-fixation. Thus, for example, G 2.0, which has practically no viral inhibitory capacity and no neuraminidase-sensitive sialic acid, nevertheless fixes tetanus toxin in proportion to its sialic acid content. Similarly, when 'slow' ganglioside is treated with neuraminidase it retains its toxin fixing capacity in proportion to its residual sialic acid.

It is notable that there are sialic acid-containing substances having biological properties that are the reverse of those of the G2 type of ganglioside, for example, ovomucoid which is an effective inhibitor of viral haemagglutination but does not fix tetanus toxin (Van Heyningen \& Miller, 1961).

The figures for the neuraminidase-sensitive sialic acid are subject to some variation and may not in every case represent maximal values, for the tendency of ganglioside to form aggregates may render them inaccessible to the enzyme bonds which would otherwise be attacked. There seem to be at least two possible explanations for differences in neuraminidase sensitivity of sialic acid in ganglioside: there may 
be more than one kind of sialic acid linkage in ganglioside, or, the gangliosides themselves may form different types of micelles in which the availability of the bonds to the enzyme differs.

In addition to the acknowledgements made in the preceding paper by van Heyningen \& Miller (1961) we wish to thank Professor R. Kuhn for samples of gangliosides, Dr G. L. Ada for crystalline neuraminidase, and Dr A. Isaacs for influenza virus and helpful advice. This work was in part supported by a grant (to W. E. van H.) from the Office of Naval Research of the United States Department of the Navy (Project No. 103-474). Grateful acknowledgement is made to the Commonwealth Fund for a Fellowship granted to A. W. B.

\section{REFERENCES}

BoGoch, S. (1957). Inhibition of viral haemagglutinin by brain ganglioside. Virology, 4, 458.

Burnet, F. M. \& Stone, J. D. (1947). The receptor-destroying enzyme of $V$. cholerae. Aust. J. exp. Biol. med. Sci. 25, 227.

Folch, J., Arsove, S. \& Meath, J. A. (1951). Isolation of brain strandin, a new type of large molecule tissue component. J. biol. Chem. 191, 819.

Howk, C. (1951). The influenza virus receptor and blood group antigens of human erythrocyte stroma. J. Immunol. 66, 9.

KLeNK, E. \& Grelen, W. (1960). Zur Kenntnis der Ganglioside des Gehirns. Z. physiol. Chem. 319, 283.

Kuns, R. (1958). 'Über die biologische Bedeutung der Aminozucker'. Proc. Fourth Int. Congr. Biochem. 1, 67.

Rosenberg, A., Howe, C. \& Chargaff, E. (1956). Inhibition of influenza virus haemagglutinin by a brain lipid fraction. Nature, Lond. 177, 234.

Svennerholm, L. (1956). On sialic acid in brain tissue. Acta chem. scand. 10, 694.

SvenNerholm, L. (1957). Quantitative estimation of sialic acids. II. A colorimetric resorcinol-hydrochloride method. Biochem. biophys. acta, 24, 604.

van Heyningen, W. E. (1959). Tentative identification of the tetanus toxin receptor in nervous tissue. J. gen. Microbiol. 20, 310.

van Heyningen, W. E. \& Milner, P. A. (1961). The fixation of tetanus toxin by ganglioside. J. gen. Microbiol. 24, 107.

WARREN, L. (1959). The thiobarbituric acid assay of sialic acids. J. biol. Chem. 234, 1971. 